\title{
Cereal-forage crop rotations and irrigation treatment effect on water use efficiency and crops sustainability in Mediterranean environment
}

\author{
Pasquale Martiniello \\ Agricultural Research Council, Unit for Extensive Animal Production, Muro Lucano (Potenza), Italy; \\ pasquale.martiniello@entecra.it, pasquale-martiniello@alice.it
}

Received 6 September 2011; revised 17 November 2011; accepted 7 December 2011

\section{ABSTRACT}

Agricultural systems based on crop rotations favour sustainability of cultivation and productivity of the crops. Wheat-forage crops rotations (annual winter binary mixture and perennial alfalfa meadow) combined with irrigation are the agronomical techniques able to better exploit the weather resources in Mediterranean environments. The experiment aimed to study the effect of 18 years of combined effect of irrigation and continuous durum wheat and wheat-forage rotations on productivities of crops and organic matter of topsoil. The experiments were established through 1991-2008 under rainfed and irrigated treatments and emphasized on the effect of irrigation and continuous wheat and wheatforage crop rotations on water use efficiency and sustainability of organic matter. The effect of irrigation increased $49.1 \%$ and $66.9 \%$ the dry matter of mixture and meadow, respectively. Continuous wheat rotation reduced seed yield, stability of production, crude protein characteristics of kernel and soil organic matter. The yearly gain in wheat after forage crops was $0.04 t$ $(\text { ha. } y r)^{-1}$ under rainfed and $0.07 \mathrm{t}(\mathrm{ha} \cdot \mathrm{yr})^{-1}$ under irrigation treatments. The crude protein and soil organic matter of wheat rotations, compared to those of continuous wheat under rainfed and irrigated was increase in term of point percentage by 0.8 and 0.5 in crude protein and 5.1 and 4.4 in organic matter, respectively. The rotations of mixture and meadow under both irrigated treatments increased the point of percentage of organic matter over continuous wheat (9.3 and 8.5 in mixture and $\mathbf{1 2 . 5}$ and $\mathbf{9 . 5}$ meadow under rainfed and irrigation, respectively). Irrigation reduce the impact of weather on crop growing reducing water use efficiency (mean over rota- tions) for dry mater production (15.5 in meadow and 17.5 in mixture [ $\mathrm{L}$ water $\left(\mathrm{kg} \cdot \mathrm{dry} \cdot \mathrm{matter}^{-1}\right.$ ] and wheat seed yield. The effect of agronomic advantages achieved by forage crops in topsoil expire its effect after three years of continuous wheat rotation.

Keywords: Alfalfa; Binary Mixture; Durum Wheat; Irrigation; Mediterranean Environment; Soil Organic Matter; Water Use Efficiency; Wheat-Forage Rotations

\section{INTRODUCTION}

Crop rotation management is the agronomic practices able safeguard ecological sustainability of the environments and fertility of the topsoil [1,2]. Comparison among experiments based on crops cultivation with chemical inputs vs crop rotations evidenced higher effect of rotation practices on gross product production, reliance of agronomic management and biological sustainability of the ecosystem. Particularly, in environments with Mediterranean-type climate, the advantages of agronomic effect of crop rotations were more evident when the effect of weather factor (e.g. drought) was weakened by agronomic management (e.g. water supply) [3,4].

The evolution of technological and social event occurred in the last Century favoured intensive farming systems with simple agronomic management of crop growing with a drastic consequence on stability and quality of crop production and turnover of soil organic matter $[2,5,6]$. However, adoption of rotation crops in farming system acknowledge agronomic benefit which reduced the ecological impact of environments on productivity and quality of agronomic gross products and on sustainability of soil organic matter $[1,2,4,7]$.

The studies aimed to assess the effect of 18 years longterm wheat forage crop rotation experiments (continuous wheat, three years of continuous wheat, annual binary 
mixture and meadow) established, under rainfed and irrigated condition of growing on productivity of the crops, qualitative characteristic of kernel, stability of seed yield and water use efficiency of crops and on chemical compounds of topsoil under weather condition of Mediterranean environment.

\section{MATERIALS AND METHODS}

\subsection{Field Trial}

The experiment was established in the farm "A. Menichella" of the Agricultural Research Council located in Foggia $\left(41^{\circ} 31^{\prime} \mathrm{N} ; 15^{\circ} 33^{\prime} \mathrm{E}\right)$ through the period 1991 to 2008. The soil was a Chromic Vertisoil with semi-arid climatic conditions (15 in the de Martonne's drought aridity index scale) [8].

The soil properties prior to the beginning of the experiment, in the $0-35 \mathrm{~cm}$ Ap horizon, had the following characteristics: coarse sand $(2-0.2 \mathrm{~mm}) 200 \mathrm{~g} \cdot \mathrm{kg}^{-1}$; fine sand $(0.2-0.02 \mathrm{~mm}) 350 \mathrm{~g} \cdot \mathrm{kg}^{-1}$; silt $(0.02-0.002 \mathrm{~mm})$ $190 \mathrm{~g} \cdot \mathrm{kg}^{-1}$; clay $(<0.002 \mathrm{~mm}) 260 \mathrm{~g} \cdot \mathrm{kg}^{-1}$; $\mathrm{pH}$ (water) 8.1; cation exchange capacity $456 \mathrm{cmole} \cdot \mathrm{g}^{-1}$; active carbonate $47.5 \mathrm{~g} \cdot \mathrm{kg}^{-1}$; total nitrogen $1.43 \mathrm{~g} \cdot \mathrm{kg}^{-1}$; organic matter $\left(\mathrm{OM}, \mathrm{g} \cdot \mathrm{kg}^{-1}\right) 25.1 \mathrm{~g} \cdot \mathrm{kg}^{-1}$; phosphorus $26 \mathrm{mg} \cdot \mathrm{kg}^{-1} ; \mathrm{C} / \mathrm{N}$ $9.8 \mathrm{~g} \cdot \mathrm{kg}^{-1}$; and potassium $1388 \mathrm{mg} \cdot \mathrm{kg}^{-1}$. The physicochemical parameters were determined according to the laboratory soil methodologies of Italian Ministry of Agricultural, Food and Forestry Policies [9]. The mean of climatic data (1990 to 2008) related to mean temperature, precipitation, evapotranspiration from a Class A water pan evaporimeter and global radiation, are shown in Table 1(a).

The durum wheat, annual binary mixture and alfalfa meadow crop rotations (referred further in text, figures and tables as wheat, mixture and meadow crop) were established under two water regime (irrigated and not irrigated which referred to throughout paper as rainfed). The average of number of water applications and the amount of water supplied to crops under irrigation were reported in Table 1(b) and Table 1(c), respectively.

The experiment was arranged in a split-plot design with irrigation as whole plots and rotations as subplots. To minimize the interaction effect of genotype, agronomic treatments and environment, the varieties used in the experiments remained the same for all period of evaluation. Three replicates were drawn up in a randomized block design. The total plots of the experiments were 78 (39 under irrigated and as many as under rainfed).

The specific rotations evaluated every year were: 3-yr annual binary mixture (berseem clover, Trifolium alexandrinum L. + barley, Hordeum vulgare L.) after 3-yr of continuous wheat (1-yr mixture, 2-yr mixture and 3-yr mixture); 3-yr alfalfa meadow (Medicago sativa L.) after wheat continuously grown for 3-yr (1-yr meadow, 2-yr
Table 1. Yearly mean of temperature, precipitation, evaporation, global radiation (section a), mean water and number of watering applied to irrigated (section $\mathrm{b}$ and $\mathrm{c}$, respectively) crop of wheat, meadow and mixture during the period of evaluation.

\begin{tabular}{|c|c|c|c|c|}
\hline Section a & $\begin{array}{l}\text { Mean T } \\
\left({ }^{\circ} \mathrm{C}\right)\end{array}$ & $\begin{array}{c}\text { Rainfall } \\
(\mathrm{mm})\end{array}$ & $\begin{array}{l}\text { ET0 } \\
(\mathrm{mm})\end{array}$ & $\begin{array}{l}\text { Radiation } \\
\left(\mathrm{MJ} \cdot \mathrm{m}^{-2}\right)\end{array}$ \\
\hline Mean & 16.1 & 444.1 & 1684 & 5236 \\
\hline Standard deviation & 0.2 & 32.5 & 32 & 105 \\
\hline \multicolumn{5}{|l|}{ Range value: } \\
\hline Lower & 14.3 & 248.4 & 1513 & 4714 \\
\hline Higher & 17.3 & 597.3 & 1897 & 5827 \\
\hline \multirow{2}{*}{ Section $\mathrm{b}$} & \multicolumn{4}{|c|}{ Waterings (n) } \\
\hline & Wheat & \multicolumn{2}{|c|}{ Mixture } & Meadow \\
\hline Mean & 3.8 & \multicolumn{2}{|c|}{3.9} & 12.6 \\
\hline Standard deviation & 0.1 & \multicolumn{2}{|c|}{0.2} & 0.3 \\
\hline \multicolumn{5}{|l|}{ Range value: } \\
\hline Lower & 3 & \multicolumn{2}{|c|}{3} & 10 \\
\hline Higher & & 14 \\
\hline \multirow{2}{*}{ Section c } & \multicolumn{4}{|c|}{ Water supply $\left(\mathrm{mm} \cdot \mathrm{ha}^{-1}\right)$} \\
\hline & Wheat & \multicolumn{2}{|c|}{ Mixture } & Meadow \\
\hline Mean & 189 & \multicolumn{2}{|c|}{192} & 632 \\
\hline Standard deviation & 6 & \multicolumn{2}{|c|}{7} & 15 \\
\hline \multicolumn{5}{|l|}{ Range value: } \\
\hline Lower & 150 & \multicolumn{2}{|c|}{150} & 500 \\
\hline Higher & 200 & & 700 \\
\hline
\end{tabular}

old meadow and 3-yr meadow old meadow); and seven durum wheat (Triticum durum Desf.) rotations (continuous wheat; 3-yr continuous wheat after a 3-yr old meadow (1-yr wheat meadow, 2-yr wheat meadow and 3-yr wheat meadow); 3-yr continuous wheat after a 3-yr continuous annual binary mixture (1-yr wheat mixture, $2-\mathrm{yr}$ wheat mixture and 3-yr wheat mixture). The rotation of old meadow and continuously annual binary mixture with 2 and 3 year, since they are used for preparing the rotation of wheat after forage crops, are not considered in the analysis of data.

For all the years of experiments, seedbeds of wheat, mixture and 1-yr meadow were prepared using a mouldboard plough that inverted soil to a depth of $35 \mathrm{~cm}$ in the $3^{\text {rd }}$ week of September in 1990. The ploughed soil was smoothed with a field cultivator and tine harrow a week later. Straw from all wheat rotations was removed from the plots before ploughing. Every year wheat and mixture rotations were fertilized in middle September during seedbed preparation using $30 \mathrm{~kg} \cdot \mathrm{ha}^{-1}$ of $\mathrm{N}$ and 31.3 $\mathrm{kg} \cdot \mathrm{ha}^{-1}$ of P. In February, when the wheat crop was at the starting of heading stage of development, a topdress of $60 \mathrm{~kg} \cdot \mathrm{ha}^{-1}$ of $\mathrm{N}$ as urea was applied to the crop. The 1-yr 
wheat meadow was fertilizer with $38.9 \mathrm{~kg} \cdot \mathrm{ha}^{-1}$ of $\mathrm{P}$ applied during seedbed preparation and in the last week of February, the old meadow of 2-yr and 3-yr meadow rotations were topdressed with $40 \mathrm{~kg} \cdot \mathrm{ha}^{-1}$ of P. Plots of rotation treatments were $12 \mathrm{~m}$ long and $8 \mathrm{~m}$ wide under irrigated and $6 \mathrm{~m}$ long and $4 \mathrm{~m}$ wide under rainfed conditions.

All crops were planted with a drill in rows $17.5 \mathrm{~cm}$ apart in October 1990. The wheat rotations were made with durum wheat variety "Ofanto", seeded at a rate of $200 \mathrm{~kg} \cdot \mathrm{ha}^{-1}$. The alfalfa rotation $(1,2$ and 3 years old meadow) was planted with alfalfa variety "Equipe". The replications of 1-yr plots were seeded in the second week of October at the density of $40 \mathrm{~kg} \cdot \mathrm{ha}^{-1}$. The mixture rotation was composed by two-rowed barley: variety "Arda" at rate of $80 \mathrm{~kg} \cdot \mathrm{ha}^{-1}$ and berseem clover: variety "Sacromonte" at $40 \mathrm{~kg} \cdot \mathrm{ha}^{-1}$. The 1-yr and in 2-yr and 3 -yr mixture crop rotations were sown in alternate rows in the second week of October of each year of evaluation.

The evapotranspitation was determined from sowing to harvest of crops according to the following water soil balance ET0 $=\Delta \mathrm{S}$ [variation in soil water storage $(\mathrm{mm})]$ + P [rainfall $(\mathrm{mm})]+\mathrm{I}$ [irrigation $(\mathrm{mm})]$. The soil water storage was measured by neutron probe $(\mathrm{mm})$ before and after irrigation supply. During the time of experiment, drainage and runoff, have been absent during the period of experiments. Water was applied when evapotranspiration (ET0) from the crop, determined by Doorenbos and Kassam [10], reached $80 \mathrm{~mm}$. In addition, in the last 5 years agreement was found from comparison of the ET0 value determined by meteorological instruments with those simulated by Decision Support System embodied in the AQUATER software for irrigation management in semi-arid Mediterranean areas [11].

The water use efficiency [WUE, $\mathrm{L}(\mathrm{kg} \cdot \mathrm{DM})^{-1}$ ] of the crops was assessed according to the procedure described by Rinaldi and Ubaldo [12]. The WUE, in the experiment under rainfed, was determined dividing the yearly DM (whole stem dry matter (DM) and seed yield (SY) in wheat; and plant DM in meadow and mixture) by the rainfall felt during growing season while the WUE of the irrigated experiment, was assessed dividing the yearly DM of the crops by the rainfall value felt during the period of experiment plus water supplied by irrigation to the crop (Table 1(c)).

Irrigation was made with a horizontal bar $16 \mathrm{~m}$ long and $125 \mathrm{~cm}$ above the soil surface applying a fix volume of water $\left(500 \mathrm{~m}^{3} \cdot \mathrm{ha}^{-1}\right)$. Nozzle pressure was $0.19 \mathrm{MPa}$ and the apparatus was moved by a hydraulic system. The watering apparatus ensure uniform water coverage and distribution on the plots. The mean of total volume of water and number of irrigations applied to the wheat, mixture and meadow, are reported in Tables 1(b) and 1(c), respectively.
Crop growth under irrigation was completed in the second week of June for wheat and last week of July for the mixture and throughout the year meadow while the growing of the rotations under rainfed treatment was finished at the first week of June. To avoid border effect, forage biomass and cereal grains were harvested at the centre of the plots (18 and 10 rows, respectively for irrigated and rainfed treatments) using experimental plot combines. Forage meadow was harvested when more than $80 \%$ of tillers in the plot had flowered while the herbage biomass of mixture was cut at barley heading in the harvest made before April and after this month, at the flowering of berseem clover. Before each harvest, plant height $(\mathrm{PH}, \mathrm{cm})$ of meadow and mixture was assessed by measuring at random six values taken from ground level to apex of stem. Forage biomass at harvest was assessed on fresh herbage from each experimental plot. The dry matter $\left(\mathrm{DM}, \mathrm{t} \cdot \mathrm{ha}^{-1}\right)$ at harvest was determined from a sample of about $500 \mathrm{~g}$ of fresh forage, dried at $65^{\circ} \mathrm{C}$ with forced ventilation for $72 \mathrm{~h}$ and then weighted for humidity determination $(\mathrm{H}, \%)$. The alfalfa leaf: stem ratio $(\mathrm{L} / \mathrm{S}$, $\%$ ) was determined using the sample utilised for moisture; stems were separated from leaves and weight and leaf DM contribution to whole stem determined. The grass: legume ratio (G/L, \% of grass over legume) in mixture was evaluated on fresh biomass sample (about 1000 g) randomly taken before harvest. The herbage components of mixture was sieved, dried for $72 \mathrm{~h}$ at $65^{\circ} \mathrm{C}$ and weight and grass contribution $(\mathrm{G} / \mathrm{L}, \%)$ to herbage determined.

Plant height $(\mathrm{PH}, \mathrm{cm})$ was determined, prior to harvest, by measuring at random six values taken from ground level to main apex of awn. Durum wheat was threshed at kernel physiological maturity. On plot basis were assessed the following traits: grain seed yield (SY, $\mathrm{t} \cdot \mathrm{ha}^{-1}$ at $13 \mathrm{~g} \cdot \mathrm{kg}^{-1}$ standard moisture content), 1000 seed weight $(\mathrm{SW}, \mathrm{g})$, test weight $\left(\mathrm{TW}, \mathrm{kg} \cdot \mathrm{hL}^{-1}\right)$, crude protein $(\mathrm{CP}$, $\%$ ), wet gluten (WG, \%) and yellow gluten index absorbance (YGIA, L reflectance degree) while seed yield compo- nents [stem density ( $\mathrm{SD}, \mathrm{stems} \cdot \mathrm{m}^{-2}$ ), seeds spike $(\mathrm{SS}, \mathrm{n})$ ]; harvest index (HI, ratio of SY and DM weight express in percentage) were determined on samples of tillers picked from two $0.5-\mathrm{m}$ sections of rows harvested prior to threshing the plot.

\subsection{Laboratory Determinations of Kernel Characteristics: CP, WG and YGIA}

The parameters were assessed on plot seed samples harvest through the years 2005 to 2008. After harvest, a sample of about $1000 \mathrm{~g}$ of kernels were air-dried in chamber with forced ventilation and stored in cool room temperature of $4^{\circ} \mathrm{C}$. The parameters were determined using the near-infrared (NIRS) spectroscopy technique 
with Foss NIRSystem monochromator scanner 6500 active in the range of $400-2500 \mathrm{~nm}$ (FOSS, Laurel MD, USA). The samples used for calibration were analyzed by laboratory standard methodology for determining the trait CP, WG and YGIA. The calibration equations were validated analyzing durum wheat flour sampling derived from ground seeds with Cyclotec mill with a mesh screen with ø of $1 \mathrm{~mm}$. Relationship among SY and kernel characteristic traits were determined according to correlation analysis testing the $r$ values with t Student's test at 10 freedom degrees [13].

\subsection{Laboratory Chemical Soil Determinations}

In September 1990 and in November 2008 (beginning and end of the rotation experiments) a soil samples were harvested for physicochemical determinations. The samples were taken from the soil surface $(0-35 \mathrm{~cm}$ Ap horizon) using a $60 \mathrm{~mm} ø$ core sampler. Twelve soil samples were harvested, at the start of experiment on grid point, on the surface where rainfed and irrigated plots treatments of the experiment, were established. At end of experiments, on area of each plot of rainfed and irrigated treatment, were collected soil samples. The total amount of samples harvested were 39 in rainfed and as many as in irrigation treatment. Thus, the total samples collected during the period of experiment were 51 (12 at beginning and 39 at the end of experiment) for rainfed and as many as for irrigated treatment.

Each soil sample was made mixing 4 cores of soil randomly drilled from plot surface and after thorough manual root separation, were air-dried and then sieved with a $2 \mathrm{~mm}$ mesh screen. The soil samples, previous laboratory determinations, were kept in the freezer at $-20^{\circ} \mathrm{C}$ those harvested at the beginning and in cool room at $4^{\circ} \mathrm{C}$ those collected at the end of experiment until they were used for laboratory determinations.

The physicochemical soil determinations: hydrometer methodology, $\mathrm{pH}$ on liquid extract of 1:2.5 soil/water solution, total nitrogen $\left(\mathrm{N}, \mathrm{g} \cdot \mathrm{kg}^{-1}\right)$, organic matte $(\mathrm{OM}$, $\left.\mathrm{g} \cdot \mathrm{kg}^{-1}\right)$, exchangeable potassium $\left(\mathrm{P}, \mathrm{mg} \cdot \mathrm{kg}^{-1}\right)$, available phosphorous $\left(\mathrm{K}, \mathrm{mg} \cdot \mathrm{kg}^{-1}\right)$, cation exchange capacity were determined according to the laboratory methodologies of the Italian Ministry of Agricultural, Food and Forest Politicises [9].

\subsection{Statistical Analyses}

Statistical analyses were conducted separately for each crop by using PROC ANOVA procedure of the SAS [14]. The model adopted for analysing the bioagronomical and quality kernel characteristics of wheat, was a factorial experimental design with a split-plot in time (year of evaluation) and space (irrigation and rotation treatments) where year, irrigation and rotation was assumed as the first, the second and the third factors of the analyses [13]. The level of each factor was: 18 for year in bioagronomic traits (Table 2(a)) and 4 in quality kernel characteristics (Table 2(b)), 2 for irrigation and 7 for rotation. The ANOVA used a mixed model with irrigation as fixed effect and year of evaluation and replication as random effects. Comparison among means of bioagronomic traits of irrigation and rotation treatments were made by least significant differences statistical test (LSD) at $\mathrm{P}>0.05$ probability level, computed on the base of appropriate error term [13].

The statistical analysis of mixture and meadow crops are processed separately comparing the effect of rotation under rainfed and irrigation treatments in common harvests (first two harvests) and the effect of rotations on all harvests of mixture and meadow of irrigation treatment ( 3 and 6 , respectively). The ANOVA of mixture and meadow, with common harvests in rainfed and irrigated condition, are processed according to factorial design with the following priority of the factor: year, irrigation, rotation and harvest with 18, 2, 3 and 2 levels, respectively while the ANOVA made on data of mixture and meadow under irrigated treatment was established according to factorial design with first factor year, the second rotation and third harvest with levels 18, 3 and 3 in mixture and 18, 3 and 6 in meadow, respectively. The comparison among mean of harvests made in rotation treatments of mixture and meadow under irrigated and rainfed was established using LSD statistical tests [13].

The effect of rotation on SY stability of durum wheat was assessed according to Eberhart and Russell [15]. The stability of SY is based on regression analysis determined using data of durum wheat SY of the rotation treatments over the period of the experiment on an independent index computed from environmental factors (soil fertility, temperature, rainfall, ET0 and global solar radiation). The stability of SY is defined by: mean of rotations treatments over the period of evaluation, regression coefficient (b, response of rotation to weather conditions) and deviation from regression $\left(\mathrm{S}^{2} \mathrm{~d}\right.$, standard deviation of mean of rotation treatments through the period of evaluation). The statistical significance of regression coefficient of rotation effect on SY was tested with $t$ Student's values with 112 degrees of freedom $\left(\mathrm{S}^{2} \mathrm{~d}\right.$ value divided pooled error) [13].

The replications data of soil chemical parameters of the rotation treatments were analyzed according to a factorial design with irrigation in the first and rotation in the 2 factor with 2 and 7 levels, respectively. Mean comparison of soil parameters value among irrigation and rotation treatments were tested using LSD at $\mathrm{P}=0.05$ level of probability. Further in the paper will be referred to the 
Table 2. Mean squares and significance of wheat forage crop rotations effects of wheat forage crop rotations on trait SY, PH, SD, SS, SW and HI (Section a) and TW, CP, WT and YGIA (Section b) under rainfed and irrigated growing condition in Mediterranean environment.

\begin{tabular}{|c|c|c|c|c|c|c|c|}
\hline Source & $\mathrm{df}$ & SY & $\mathrm{PH}$ & SD & SS & SW & HI \\
\hline (a) & & \multicolumn{6}{|c|}{ Bioagronomic characteristic } \\
\hline Year (Y) & 17 & $4.5^{* *}$ & $31.1^{*}$ & $619^{*}$ & $497 * *$ & $26^{*}$ & $25^{*}$ \\
\hline Irrigation (I) & 1 & $17.7 * *$ & $2134 * *$ & $3330 * *$ & $3835^{* *}$ & $1419^{* *}$ & $2334 * *$ \\
\hline Rotation (R) & 6 & $23.7 * *$ & $159 * *$ & $53729 * *$ & $6648 * *$ & $44 * *$ & $105^{* *}$ \\
\hline \multicolumn{8}{|l|}{ Interaction: } \\
\hline $\mathrm{I} \times \mathrm{Y}$ & 17 & $0.7 * *$ & $204 * *$ & $11091 * *$ & $1137 * *$ & $153^{* *}$ & $57 * *$ \\
\hline $\mathrm{R} \times \mathrm{Y}$ & 102 & $1.4^{* *}$ & $62 * *$ & $4783 * *$ & $3531 * *$ & $20 * *$ & $28 * *$ \\
\hline $\mathrm{I} \times \mathrm{R}$ & 6 & $6.9^{* *}$ & $242 * *$ & $4622 * *$ & $101 \mathrm{NS}$ & $72 * *$ & $17 *$ \\
\hline $\mathrm{I} \times \mathrm{R} \times \mathrm{Y}$ & 102 & $0.9^{* *}$ & $24 * *$ & $3130 * *$ & $3021 * *$ & $78 * *$ & $70^{* *}$ \\
\hline Pooled error & 504 & 0.2 & 14 & 2643 & 109 & 6 & 12 \\
\hline Source & $\mathrm{df}$ & TW & $\mathrm{CP}$ & WG & YGIA & & \\
\hline (b) & & \multicolumn{6}{|c|}{ Qualitative characteristic of kernel } \\
\hline Year (Y) & 3 & $4.7^{*}$ & $4.1^{*}$ & $4.9 *$ & $11.7 * *$ & & \\
\hline Irrigation (I) & 1 & $28 * *$ & $0.4 * *$ & $2.2 * *$ & $64.0^{* *}$ & & \\
\hline Rotation (R) & 6 & $10^{* *}$ & $20.2 * *$ & $48.7 * *$ & $9.3 * *$ & & \\
\hline \multicolumn{8}{|l|}{ Interaction: } \\
\hline $\mathrm{I} \times \mathrm{Y}$ & 3 & $11 * *$ & $7.2 * *$ & $32.0 * *$ & $5.7 * *$ & & \\
\hline $\mathrm{R} \times \mathrm{Y}$ & 18 & $0.2 \mathrm{NS}$ & $7.4 * *$ & $21.8^{* *}$ & $2.0 * *$ & & \\
\hline $\mathrm{I} \times \mathrm{R}$ & 6 & $2.9^{* *}$ & $4.5^{* *}$ & $13.8^{* *}$ & $1.8^{*}$ & & \\
\hline $\mathrm{I} \times \mathrm{R} \times \mathrm{Y}$ & 18 & $4.8^{* *}$ & $1.8^{* *}$ & $10.4 * *$ & $1.4^{*}$ & & \\
\hline Pooled error & 112 & 0.2 & 0.4 & 0.9 & 0.7 & & \\
\hline
\end{tabular}

* and **: statistical significant at 0.05 and 0.01 probability level, respectively. NS: not significant.

relationships among agronomic effect wheat forages crop rotations under rainfed and irrigated on water use efficiency, productivity and sustainability of crops and OM of topsoil.

\section{RESULTS}

\subsection{Durum Wheat}

The ANOVA revealed in all traits a significant effect of main factors: years, rotations and irrigated treatments. The variation of mean square values of rotation over irrigation treatments was a consequence of the higher effect of wheat rotation than irrigation treatments (Tables 2(a), 2(b)). The lack of statistical significance observed in the two way $(\mathrm{I} \times \mathrm{R})$ and $(\mathrm{R} \times \mathrm{Y})$ and three way interaction factors $(\mathrm{I} \times \mathrm{R} \times \mathrm{Y})$ in $\mathrm{SY}$ components traits $(\mathrm{SS}$, $\mathrm{HI}$ and TW) were ascribed to relationships among ex- perimental factors with weather condition which influenced the adaptability and the development of the crop in the environment (Table 2(a)). The variation in absolute mean square values of rotation and irrigation treatments was due to the effect of agronomic treatment occurred during the period of evaluation on crop development. The lack of statistical significance in SS in the two way interaction $(\mathrm{I} \times \mathrm{R})($ Table $2(\mathbf{a}))$ and $(\mathrm{R} \times \mathrm{Y})$ in TW $($ Table 2(b)) may ascribed to reduced agronomic effect of irrigation and rotation treatments during the years evaluation (Table 2(a)).

The reduced mean square values of the two- and threeway interaction factors, in comparison to main factors, were ascribed to relationships among experimental factors with weather condition which influenced the adaptability and the development of the crop in the environment (Tables 2(a) and (b)). The mean values over the 
years of 1-yr, 2-yr and 3-yr rotations under rainfed of wheat mixture and wheat meadow increased SY of continuous wheat (Figure 1(a)).

The beneficial effect of wheat meadow and wheat mixture (mean of 1-yr, 2-yr and 3-yr) rotation treatments on continuous wheat, increased SY by $28 \%$ and $6.7 \%$ under rainfed and $33.8 \%$ and $24.3 \%$ under irrigated treatment, respectively (Figure 1(a)). Similar trend was observed for irrigation treatment on 1-yr, 2-yr and 3-yr wheat meadow rotations $(18.1 \%, 25.3 \%$ and $25.3 \%$ in comparison to those under rainfed, respectively) (Figure 1(a)).

The combined effect of rotation with irrigation treatments on SY was higher expressed in 1-yr wheat meadow and wheat mixture than those of 2-yr and 3-yr rotations $(12.3 \%$ and $17.3 \%, 10.1 \%$ and $15.9 \%$ in wheat mixture, respectively) (Figure 1(a)). The agronomic ef- fect on SY trait of irrigation and rotation treatments in wheat mixture rotations in comparison to those of wheat meadow was reduced by $25.2 \%$ and $11.9 \%$ under rainfed and irrigated condition, respectively. Furthermore, the SY of 1-yr wheat-mixture under irrigation was $12.1 \%$ and $19.8 \%$ higher than $2-y r$ and 3-yr rotations, respectively while the effect of rotation treatment was reduced only among wheat mixture rotations under rainfed (Figure 1(a)).

The SY component traits of the continuous wheat, wheat meadow and wheat mixture rotations under irrigation treatment were strongly affect than rainfed. Among them, SW, SS, HI and SD were the traits more influenced by rotation and irrigation treatments (data not shown). The effect of irrigation interferes with WUE values among whole stem of wheat meadow, wheat mixture, meadow
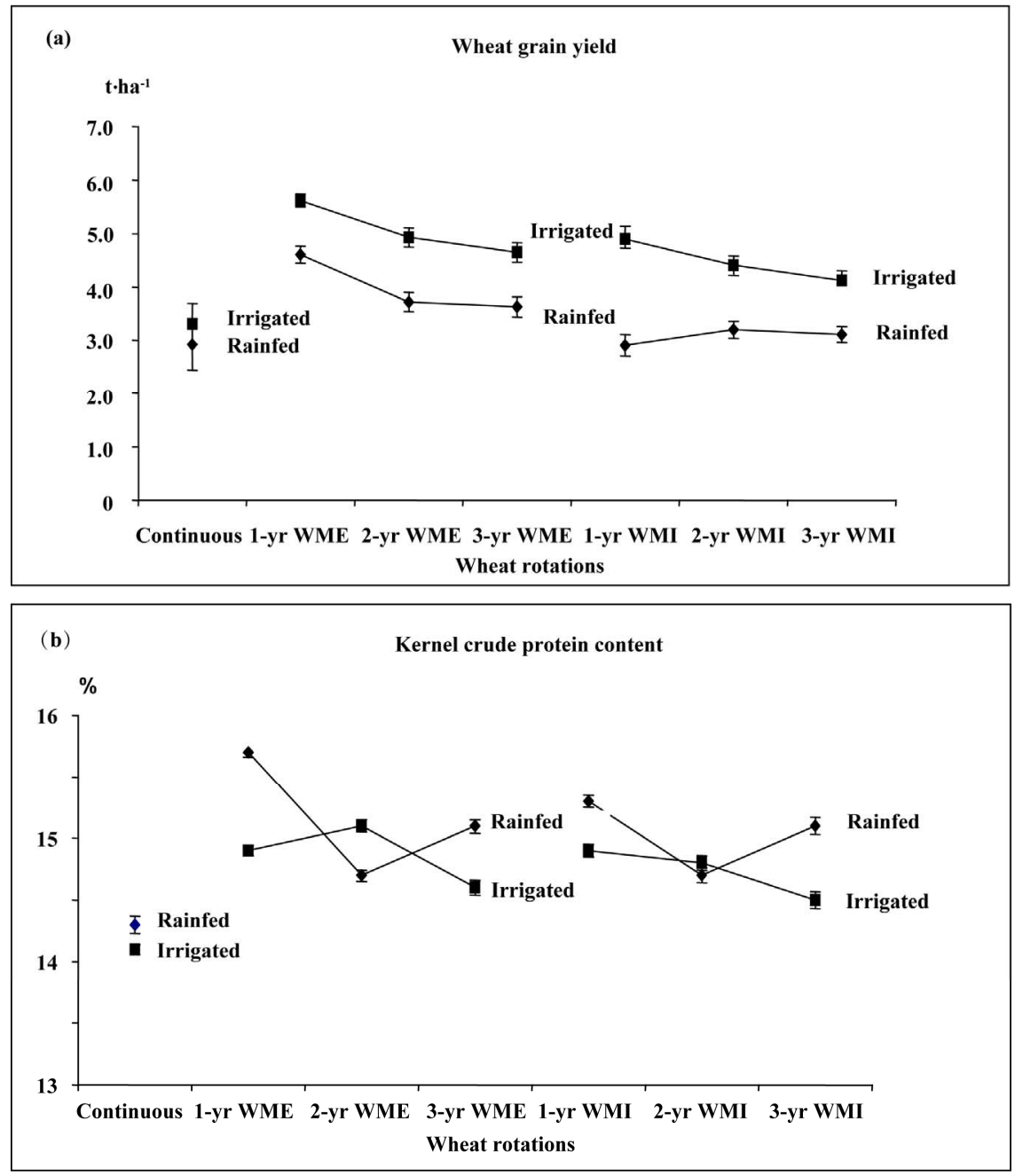

Figure 1. Yearly mean of SY and their standard error (vertical bars) (graph a) and CP content (graph b) of wheat forage crop rotations (Continuous, 1-yr WME, 2-yr WME and 3-yr WME, 1-yr WMI, 2-yr WMI and 3-yr WMI refer to rotations: continuous wheat, 1-yr, 2-yr and 3-yr wheat-meadow and wheat mixture, respectively) under rainfed and irrigated in Mediterranean environment. 
and mixture rotations (Table 3). In biomass whole plant, the WUE range from 34 to 36,35 to 38,77 to 85 , and 88 to 94 under rainfed and 38 to 41,44 to 47,61 to 74 and 66 to 81 under irrigated condition, respectively (Table 3) while in SY of wheat meadow and wheat mixture rotations was $69.8 \%$ and $74.4 \%$ under rainfed and $69.2 \%$ and $68.7 \%$ under irrigation treatment higher than those of whole stem, respectively (Table 3). Furthermore, the WUE values of whole stem and SY of continuous wheat under both condition of growing were higher than wheat meadow and wheat mixture rotations (Table 3). In SY trait, the lower value of WUE of 1-yr wheat meadow and wheat mixture than those of $2-\mathrm{yr}$ and $3-\mathrm{yr}$ rotations (wheat meadow: $20 \%$ and $22.6 \%$ under rainfed and $10.8 \%$ and $16.7 \%$ under irrigate and wheat mixture: $10.3 \%$ and $18.2 \%$ under irrigated, respectively) evidenced that the benefit of forage crop rotations expired its effect since the 2-yr wheat rotation (Figure 1(a), Table 3 ).

The higher values of WUE of whole stem and SY of the wheat meadow and wheat mixture rotations under irrigated over rainfed treatment $(10.2 \%$ and $11.0 \%$ in rainfed and $18.4 \%$ and $3.2 \%$ in irrigated for whole plant and SY, respectively), was a consequence of the delayed period of threshing caused by irrigation treatment while the reduced WUE observed in continuous wheat $(9.4 \%$ and $5.0 \%$ in rainfed and $18.0 \%$ and $33.6 \%$ in irrigated for whole plant and SY, respectively) was ascribed to lack of crop rotation benefit of forage crops rotations (Table 3 ).

The agronomic effect of irrigation on rotation treatments of wheat meadow, wheat mixture and continuous wheat evidenced by Eberhart and Russell's [15] regression analyses reduced the impact weather of crop over period of 18 years of evaluation. The higher values of $b$ and $\mathrm{S}^{2} \mathrm{~d}$ of continuous wheat rotations under rainfed than those of irrigated ( 0.82 vs. 0.63 in b and $280.1^{* *}$ vs. $75.1^{*}$ in $\mathrm{S}^{2} \mathrm{~d}$ ) was attributed to reduced environmental impact of irrigation on plant development across the years of evaluation. Greater advantages of wheat meadow and wheat mixture rotation was achieved in 1-yr rotation under rainfed treatment whose mean of SY increased over continuous wheat by $38.9 \%$ in wheat meadow and $5.1 \%$ in wheat mixture and reduced $\mathrm{b}$ values and $\mathrm{S}^{2} \mathrm{~d}\left(\mathrm{~b}, 0.82,0.72,0.78\right.$ and $\mathrm{S}^{2} \mathrm{~d}, 280.1 * *, 78.2 *$, $98.2^{*}$ in continuous, 1-yr wheat meadow and wheat mixture, respectively).

The content of kernel qualitative chemical characteristics was related to wheat-meadow and wheat-mixture rotations rather than irrigated treatments. The values of continuous wheat, wheat meadow and wheat mixture rotations of kernel qualitative characteristics under irrigation treatment were lower than those of rainfed. Furthermore, the discrepancy among traits of 1-yr, 2-yr and
Table 3. WUE in wheat whole plant and SY of continuous wheat, wheat meadow and wheat mixture and in whole plant of meadow and mixture in wheat forage crop rotation treatments under rainfed and irrigated condition in Mediterranean environment.

\begin{tabular}{|c|c|c|c|c|c|}
\hline \multicolumn{6}{|c|}{ Water use efficiency $\left[\mathrm{L}\right.$ water $\left.(1 \mathrm{~kg} \cdot \mathrm{DM})^{-1}\right]$} \\
\hline Rotation & $\begin{array}{c}\text { Continuous } \\
\text { wheat }\end{array}$ & $1-\mathrm{yr}$ & $2-\mathrm{yr}$ & $3-\mathrm{yr}$ & $\begin{array}{l}\text { LSD } \\
0.05\end{array}$ \\
\hline \multicolumn{6}{|c|}{ Rainfed } \\
\hline \multicolumn{6}{|l|}{ Wheat-meadow } \\
\hline Whole stem & 39 & 36 & 34 & 36 & 2 \\
\hline Seed yield & 152 & 96 & 120 & 124 & 6 \\
\hline \multicolumn{6}{|l|}{ Wheat-mixture } \\
\hline Whole stem & & 35 & 37 & 38 & 2 \\
\hline Seed yield & & 153 & 148 & 147 & 5 \\
\hline Meadow & & 85 & 77 & 81 & 3 \\
\hline Mixture & & 94 & 88 & 89 & 4 \\
\hline \multicolumn{6}{|c|}{ Irrigated } \\
\hline \multicolumn{6}{|l|}{ Wheat-meadow } \\
\hline Whole stem & 48 & 38 & 39 & 41 & 3 \\
\hline Seed yield & 192 & 115 & 129 & 138 & 6 \\
\hline \multicolumn{6}{|l|}{ Wheat-mixture } \\
\hline Whole stem & & 44 & 44 & 47 & 3 \\
\hline Seed yield & & 140 & 145 & 159 & 6 \\
\hline Meadow & & 74 & 62 & 61 & 2 \\
\hline Mixture & & 81 & 60 & 78 & 2 \\
\hline
\end{tabular}

3-yr of wheat meadow under rainfed and irrigated treatments was lower than those of wheat mixture (data not shown). Among traits, CP was the parameter with significant correlation $r$ values under both rainfed and irrigated treatment $\left(0.65^{*}\right.$ and $0.88^{* *}$ with $\mathrm{n}=10 \mathrm{df}$, respectively). The CP mean value of continuous wheat was lower $5.9 \%$ and $2.1 \%$ under rainfed and $5.4 \%$ and $4.1 \%$ under irrigated in wheat meadow and wheat mixture, respectively (Figure 1(b)). The mean CP of continuous wheat and wheat meadow under rainfed was $1.4 \%$ and $2.0 \%$ higher than irrigation treatment, respectively. No variation was observed in $\mathrm{CP}$ in wheat mixture under both rainfed and irrigated condition (Figure 1(b)).

\subsection{Forage Crops}

The ANOVA of the common I and II harvests under rainfed and irrigated treatment of mixture and meadow rotations revealed mean square value of irrigation higher 

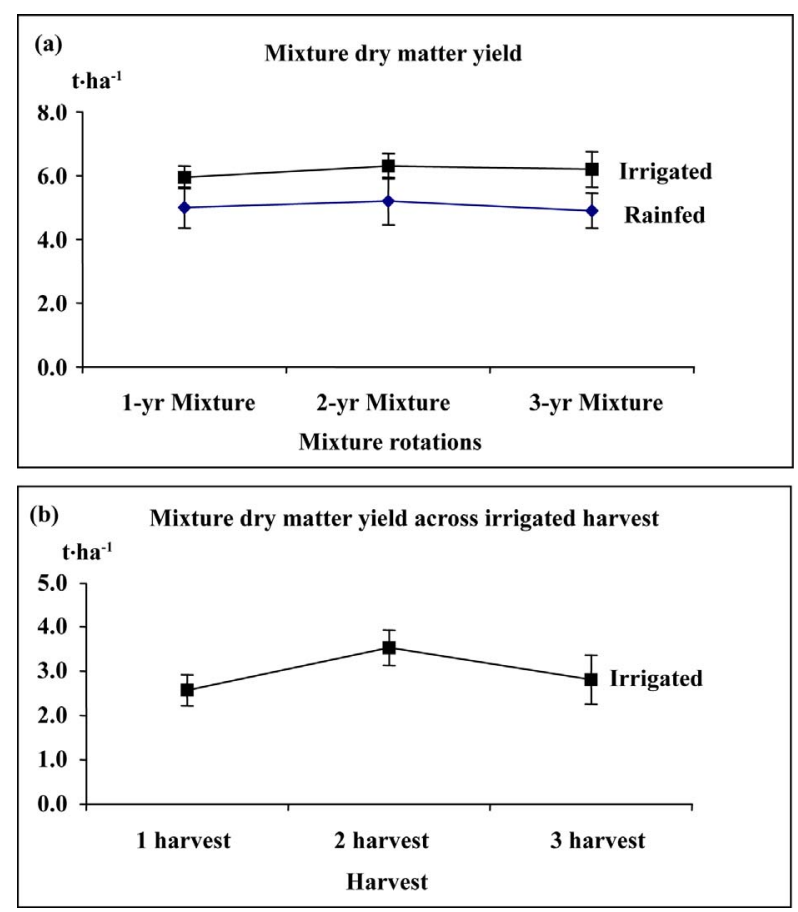

Figure 2. Yearly DM mean of mixture rotations and their standard error (vertical bars) (graph a) under both irrigation treatment and mixture DM in irrigated harvests (graph b) in Mediterranean environment.

than those of year, rotation and harvest (Table 4). The reduced mean square values of the irrigation treatment observed in DM trait in mixture in comparison to those of meadow was ascribed to the adaptability of the crop to growth under Mediterranean weather condition. The mean square variability existing among two- and threeway interaction factors resulted from different effects of agronomic treatments on regrowth after plant defoliation. However, the lack of statistical significance in DM among two- $(\mathrm{I} \times \mathrm{Y}$ and $\mathrm{R} \times \mathrm{H})$ and three-way $(\mathrm{I} \times \mathrm{R} \times \mathrm{Y})$ interaction factors in mixture rather than meadow was due to spring vegetative stasis which reduced the effect of irrigation and rotation treatments and did not interfere with plant development after defoliation (Table 4, Figure 2(a)). The reduced relationship between rotations and harvests, in mixture under rainfed and irrigated treatment, was evidenced by low coefficient of determination $\mathrm{R}^{2}$ values (0.11 and 0.48 , respectively).

The DM of 1-yr, 2-yr and 3-yr rotations mixture of rainfed was $19.7 \%$ lower than those of irrigated and did not show variation among rotations in both irrigation treatments (Figure 2(a)). The lack of significance in DM yield and PH of two- $(\mathrm{I} \times \mathrm{R}),(\mathrm{I} \times \mathrm{Y})$ and $(\mathrm{H} \times \mathrm{R})$ and $\mathrm{DM}$ in three- $(\mathrm{I} \times \mathrm{R} \times \mathrm{Y})$ way factor interactions, evidenced that the factors year, irrigation and rotation treatments not interfered with plant development, limiting DM production of 1-yr, 2-yr and 3-yr rotations of II harvest mixture under irrigated in comparison to those of rainfed (Figure 2(a), Table 4).

The low coefficient of determination $\left(\mathrm{R}^{2}=0.06\right)$ between DM and rotation treatments under irrigated condition of growing evidenced that DM of harvests was not influenced by rotations. Analogous relationships were found in the mean DM values of rotations within the harvests under irrigated treatment (Figure 2(b)). However, the reduced DM yield in the III harvest than others was due to the effect of weather condition on vegetative stasis which reduced the efficiency of physiological process of plant development (III harvest was 8.2\% higher and 20.6\% lower than I and II harvest, respectively) (Figure 2(b)).

The variation of yearly meadow DM in rainfed and irrigated treatment (5.53 and $7.13 \mathrm{t} \cdot \mathrm{ha}^{-1}$, respectively) was due to the effect of irrigation treatment on plant development. The DM production and irrigation was linearly correlated $\left(\mathrm{R}^{2}=0.16\right.$ for rainfed and $\mathrm{R}^{2}=0.25$ for irrigated condition) (Figure 3(a)). Thus, the trend of yearly DM increase in the rotations under irrigation $(22.4 \%$ higher than rainfed) was due to the agronomic effect of
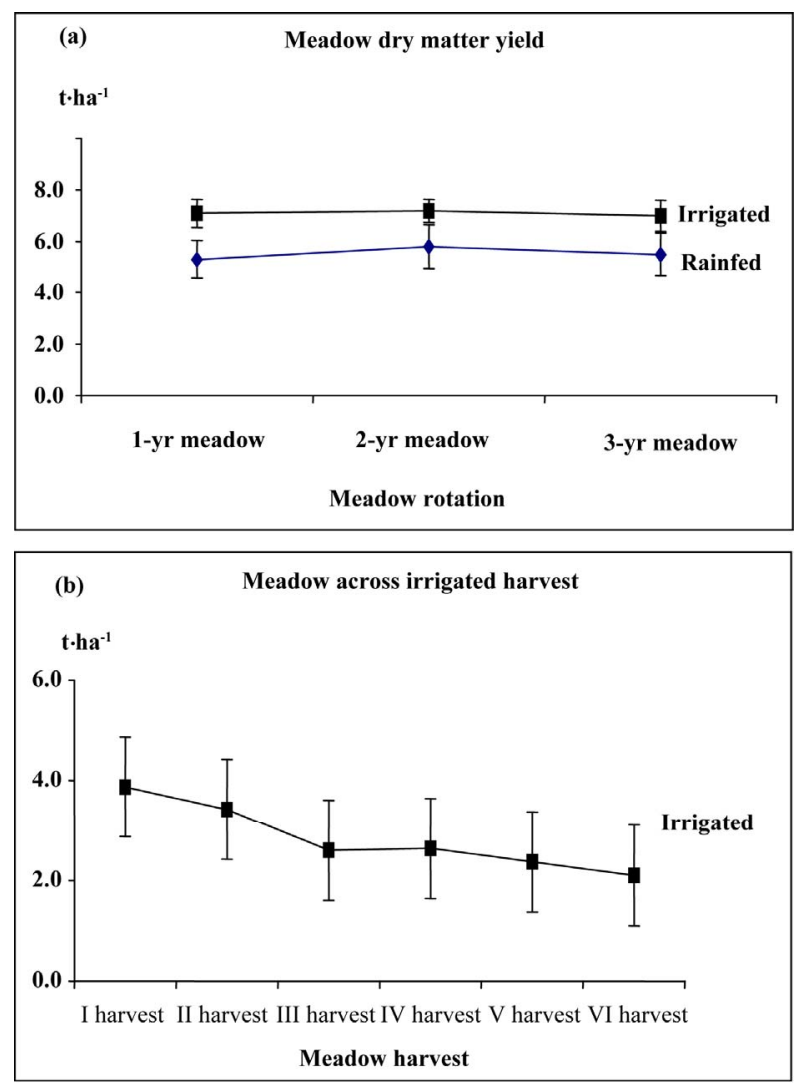

Figure 3. Yearly DM mean of meadow rotations and their standard error (vertical bars) (graph a) under both irrigation treatments and meadow DM in irrigated harvests (graph b) under rainfed and irrigated condition in Mediterranean environment. 
Table 4. Mean squares and significance of forage crops rotations effects on bioagronomic traits of mixture (section a) and meadow (section b) under rainfed and irrigated growing condition in Mediterranean environment.

\begin{tabular}{|c|c|c|c|c|c|c|c|}
\hline Source & $\mathrm{df}$ & DM & $\mathrm{PH}$ & GS & $\mathrm{H}$ & $\mathrm{G} / \mathrm{L}$ & $\mathrm{L} / \mathrm{S}$ \\
\hline \multicolumn{8}{|l|}{ a) Mixture } \\
\hline Year (Y) & 17 & $12.5^{* *}$ & $35^{*}$ & $7877 *$ & $28^{*}$ & $85^{*}$ & $91^{*}$ \\
\hline Irrigation (I) & 1 & $806^{* *}$ & $4887 * *$ & $52175^{* *}$ & $169 * *$ & $11.0 * *$ & $117 * *$ \\
\hline Rotation (R) & 2 & $10.1 \mathrm{NS}$ & $36 \mathrm{NS}$ & $27230 \mathrm{NS}$ & $24 \mathrm{NS}$ & $15^{* *}$ & $141 * *$ \\
\hline \multicolumn{8}{|l|}{ Interaction: } \\
\hline $\mathrm{I} \times \mathrm{Y}$ & 17 & $0.5 \mathrm{NS}$ & $36^{* *}$ & $23564 * *$ & $26^{* *}$ & $11 * *$ & $190 * *$ \\
\hline $\mathrm{R} \times \mathrm{Y}$ & 51 & $10.9^{* *}$ & $697 * *$ & $29782 * *$ & $320 * *$ & $68 * *$ & $441 * *$ \\
\hline $\mathrm{I} \times \mathrm{R}$ & 2 & $4.5 \mathrm{NS}$ & $23 \mathrm{NS}$ & $22953 * *$ & $31 * *$ & $14 * *$ & $32 * *$ \\
\hline $\mathrm{I} \times \mathrm{R} \times \mathrm{Y}$ & 51 & $0.6 \mathrm{NS}$ & $46^{* *}$ & $21084 * *$ & $26^{* *}$ & $11 * *$ & $48 * *$ \\
\hline Pooled error & 182 & 3.7 & 6 & 3618 & 5 & 4 & 5 \\
\hline Source & $\mathrm{df}$ & DM & $\mathrm{PH}$ & SD & $\mathrm{H}$ & & $\mathrm{L} / \mathrm{S}$ \\
\hline \multicolumn{8}{|l|}{ b) Meadow } \\
\hline Year (Y) & 17 & $1.4^{*}$ & $81^{* *}$ & $3130^{* *}$ & $17^{*}$ & & $25^{*}$ \\
\hline Irrigation (I) & 1 & $1907 * *$ & $30917 * *$ & $43335 * *$ & $129 * *$ & & $3133 * *$ \\
\hline Rotation (R) & 2 & $5.1^{* *}$ & $1843 * *$ & $31858 * *$ & $15^{*}$ & & $42 * *$ \\
\hline \multicolumn{8}{|l|}{ Interaction: } \\
\hline $\mathrm{I} \times \mathrm{Y}$ & 17 & $10.0^{* *}$ & $92 * *$ & $16465 * *$ & $39 * *$ & & $15^{* *}$ \\
\hline $\mathrm{Y} \times \mathrm{R}$ & 51 & $5.8^{* *}$ & $544 * *$ & $49562 * *$ & $127 * *$ & & $51 * *$ \\
\hline $\mathrm{I} \times \mathrm{R}$ & 2 & $4.2 * *$ & $245^{* *}$ & $16377 * *$ & $64 * *$ & & $36 * *$ \\
\hline $\mathrm{I} \times \mathrm{R} \times \mathrm{Y}$ & 51 & $0.5^{*}$ & $44^{*}$ & $7697 * *$ & $21 *$ & & $20 * *$ \\
\hline Pooled error & 182 & 0.3 & 27 & 241 & 4 & & 4 \\
\hline
\end{tabular}

* and **: statistical significant at 0.05 and 0.01 probability level, respectively. NS, not significant.

irrigation treatment which favours plant growth than rainfed (Figure 3(a)). The effect of irrigation on meadow rotations rather than rainfed favours summer vegetative growth which increased the period of crop utilization and number of harvests and as consequences yearly DM production (Figure 3(b)). The lower harvest number of mixture than meadow was a consequence of environmental factors which (light, photoperiod and temperature) determine summer vegetative stasis of mixture crop. The mean differences of DM among meadow rotations under irrigated condition between first and last harvest (I harvest minus the VI harvest) amount to $2.03 \mathrm{t} \cdot \mathrm{ha}^{-1}$ (Figure 3(b)). The linear decline of DM through the harvests was due to senescence of plant development $\left(R^{2}=0.89\right)$ during vegetative cycle which reduced PH $(8.7 \mathrm{~cm})$, SD $(90$ stems $\cdot \mathrm{m}^{-2}$ ), and increased L/S (7.1\%) (data not shown).

The beneficial effect of irrigation on both forage crops favours plant development and lower values of WUE in meadow and mixture (Table 3). The reduced values of WUE in 2-yr and 3-yr meadow and mixture rotations in comparison to those of $1-\mathrm{yr}$, was related to the effect of rotation on soil OM parameter (Figure 4(b)). However, the lower WUE values of meadow rotations than those of mixture was due to different edaphic adaptability of the crops to weather conditions of the environment, which reduced the sensitivity to vegetative stasis which allowed physiological characteristics able to better exploit the agronomic effect of irrigation treatment (Table 3).

The irrigation reduced the effect of weather stress on the physiological processes which underline the development of forage crop favouring higher WUE than rainfed (mean over rotation treatments of meadow and mixture: 84 and $90\left[\mathrm{~L}(\mathrm{~kg} \cdot \mathrm{DM})^{-1}\right]$ under rainfed vs 66 and 73 $\mathrm{L}\left[\mathrm{L}(\mathrm{kg} \cdot \mathrm{DM})^{-1}\right]$ under irrigated treatment, respectively) (Table 3). Furthermore, the reduced sensitivity of meadow in comparison to mixture to vegetative stasis con- 

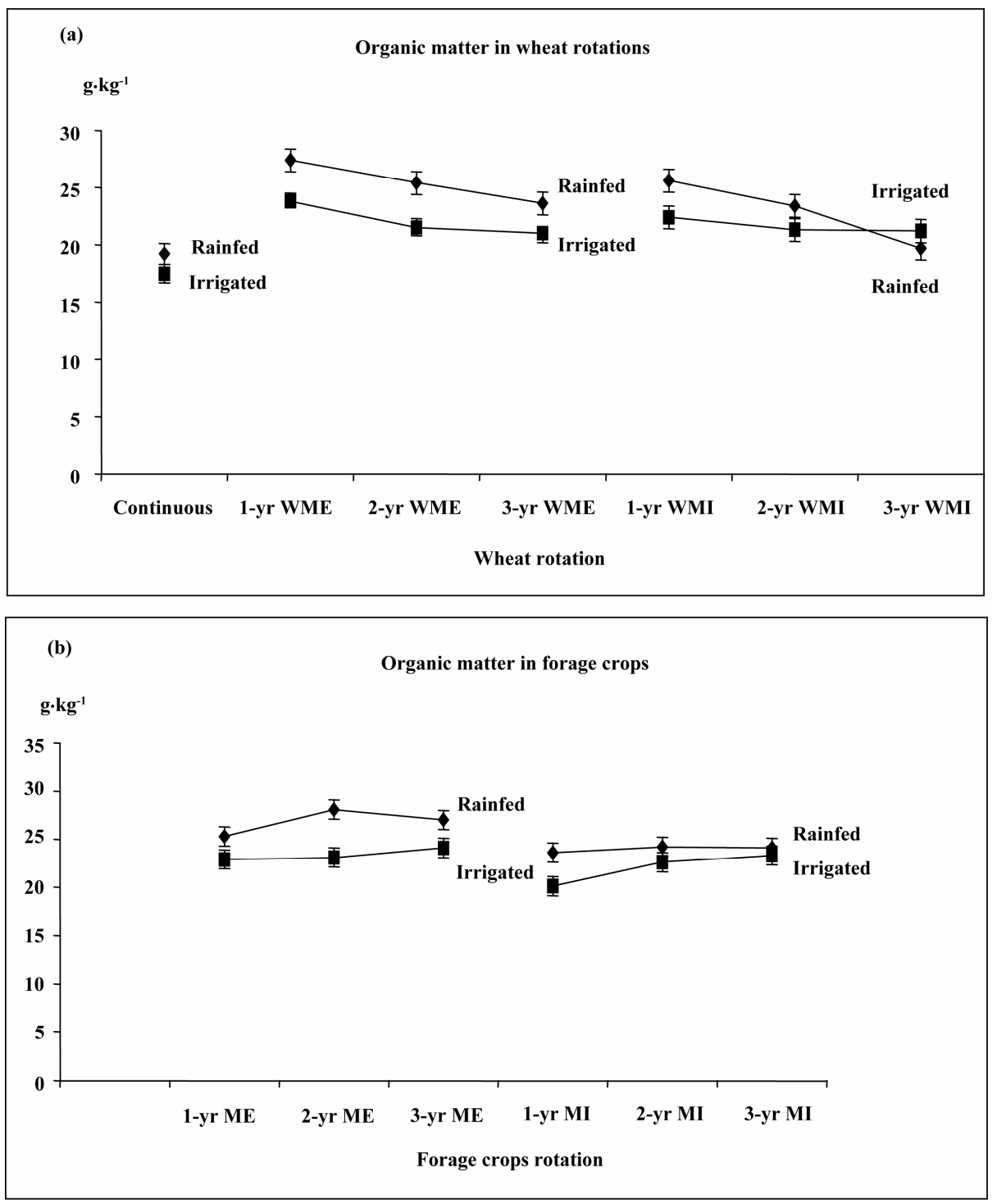

Figure 4. Mean of OM content in topsoil of wheat rotations (Continuous, 1-yr WME, 2-yr WME and 3-yr WME, 1-yr WMI, 2-yr WMI and 3-yr WMI refer to rotations: continuous wheat, 1-yr, 2-yr and 3-yr wheat-meadow and wheat mixture, respectively) and their standard error (vertical bars) (graph a) and meadow and mixture rotations (1-yr ME, 2-yr ME and 3-yr ME, 1-yr MI, 2-yr MI and 3-yr MI refer to rotations: 1-yr, 2-yr and 3-yr meadow and mixture, respectively).

ferred longer period of agronomic exploitation (3 harvests in mixture and 6 harvests in meadow) which determine higher gap between rainfed and irrigated DM yield production $\left(1.61 \mathrm{t} \cdot \mathrm{ha}^{-1}\right.$ in mixture and $10.61 \mathrm{t} \cdot \mathrm{ha}^{-1}$ in meadow) (Figures 2(b), 3(b)).

\subsection{Effect of Wheat Forage Crop Rotations on OM of Topsoil}

The agronomic effect of forage crop rotations influenced mainly the turnover of OM of topsoil and sustainability of crop development. The difference of mean over rotation treatments in OM content at beginning of ex- periment (materials and methods, Subsection 2.1) and those recorded at the end of trail, was higher reduced in continuous wheat than other wheat and forage crop rotations (Figures 4(a) and 4(b)). Continuous wheat rotations reduced the content of OM, over a period of 18 years, $\left(25.1 \mathrm{~g} \cdot \mathrm{kg}^{-1}\right.$ at the beginning of experiment) by 5.9 and $7.6 \mathrm{~g} \cdot \mathrm{kg}^{-1}$ under rainfed and irrigated condition, respectively (Figure 4(a)).

The mean values of OM recorded at the end of experiment on wheat meadow and wheat mixture rotations (25.4 and $22.9 \mathrm{~g} \cdot \mathrm{kg}^{-1}$ under rainfed and 22.1 and 21.6 $\mathrm{g} \cdot \mathrm{kg}^{-1}$ under irrigated, respectively) was higher in wheat 
meadow $\left(0.4 \mathrm{~g} \cdot \mathrm{kg}^{-1}\right)$ and lower in wheat mixture $(2.2$ $\mathrm{g} \cdot \mathrm{kg}^{-1}$ ) under rainfed while under irrigated condition, the content of OM in all wheat forage rotations, was lower than the value recorded at beginning of experiment $(2.2$ $\mathrm{g} \cdot \mathrm{kg}^{-1}$ in wheat meadow and $3.5 \mathrm{~g} \cdot \mathrm{kg}^{-1}$ in wheat mixture) (Figure 4(a)).

Among wheat forage rotations, the content of $\mathrm{OM}$ in $1-y r$ wheat meadow and 1-yr wheat mixture rotations at end of experiment, under rainfed was higher (2.3 and 0.5 $\mathrm{g} \cdot \mathrm{kg}^{-1}$, respectively) than the value recorded at the beginning while in the $3-\mathrm{yr}$ wheat forage rotations, the values of $\mathrm{OM}$ were reduced $\left(1.5\right.$ and $5.4 \mathrm{~g} \cdot \mathrm{kg}^{-1}$ in wheat meadow and wheat mixture, respectively) (Figure 4(a)). By contrast, the $\mathrm{OM}$ mean content of rotations under irrigated condition, in wheat meadow and wheat mixture at end of experiments was lower $2.4 \mathrm{~g} \cdot \mathrm{kg}^{-1}$ and 3.5 $\mathrm{g} \cdot \mathrm{kg}^{-1}$ than the content of the beginning of experiment, respec- tively (Figure 4(a)).

The content of OM under irrigated condition was 2.8 $\mathrm{g} \cdot \mathrm{kg}^{-1}$ in wheat meadow and $1.3 \mathrm{~g} \cdot \mathrm{kg}^{-1}$ and wheat mixture lower than rainfed (Figure 4(a)).

The mean values of OM in meadow and mixture rotations at end of experiment, in contrast to the content of $\mathrm{OM}$ of continuous wheat $\left(5.9 \mathrm{~g} \cdot \mathrm{kg}^{-1}\right.$ in rainfed and 7.6 $\mathrm{g} \cdot \mathrm{kg}^{-1}$ in irrigated), were lower 0.6 and $1.1 \mathrm{~g} \cdot \mathrm{kg}^{-1}$ under rainfed and 1.7 and $3.1 \mathrm{~g} \cdot \mathrm{kg}^{-1}$ under irrigation than those present at beginning of experiment, respectively (Figure 4(b)).

The lower variation observed among the OM recorded in 1-yr, 2-yr and 3-yr meadow and mixture rotations under rainfed than irrigated treatment, evidenced a reduced effect of meadow and mixture rotations on development of crops (Figure 4(b)). The variation observed among rotations wheat meadow and wheat mixture of irrigated condition, compared to those of rainfed, was due to higher input residues left in the soil by meadow and mixture crops under irrigated rotations than those under rainfed (Figures 4(a) and 4(b)). However, the higher OM achieved by forage crops under rainfed and irrigated treatments on wheat meadow and wheat mixture rotations was vanished after 3-yr of continuous wheat rotations (Figures 4(a) and 4(b)).

\section{DISCUSSION}

\subsection{Wheat Forage Crop Rotations}

The SY difference existing in wheat rotations was a consequence of relationship among experimental factors on agronomic effect in wheat forage crop rotations than continuous wheat under rainfed and irrigated treatment (17.8\% and 30.6\%, respectively) (Figure 1(a)). The better SY performance, evidenced by Erberhart and Russell's [15] parameters, in wheat meadow and wheat mixture mean rotations than continuous wheat was a cones- quence of agronomic effect of rotations and irrigation treatments which buffered the environmental constrain during wheat crop development [7,16,17] (Figure 1(a)). The weakened of agronomic effect on SY stability and SY production under rainfed and irrigated condition, in the 2-yr and 3-yr rotations was related to content of OM in the topsoil whose effect reduced SY and increase $S^{2} d$ (data not shown) (Figures 1(a) and 4(b)) $[4,18]$.

The variation existing between SY and SY component traits in rainfed and irrigated treatment in continuous wheat, wheat meadow and wheat mixture rotations was a consequence of reduced effect of environmental stress on plant development in Mediterranean-type climate [19,20]. According to García del Moral and Rharrabti [5] and Martiniello [4], the reduced variation (difference between 1-yr and 3-yr rotations) between SY in wheat meadow and wheat mixture rotations under irrigated (1.12 and $0.93 \mathrm{t} \cdot \mathrm{ha}^{-1}$, respectively) rather than rainfed $\left(0.76 \mathrm{t} \cdot \mathrm{ha}^{-1}\right.$ wheat meadow) was due to the effect of OM left in the soil by meadow than mixture rotations (Figures 1(a), 4(a) and 4(b)).

The correlated variation of CP content with SY observed in rainfed and irrigated condition of the continuous wheat and wheat forage crops rotations was conesquences of environmental effect of physiological process on relocation of stored compound in the sink organs (Figure 1(b)). According to the results found by García del Moral and Rharrabti [5], the reduced variation over mean $\mathrm{CP}$ of wheat forage crops rotations under rainfed and irrigated $(1.9 \%$ and $0.6 \%$, respectively) was due to reduced effect of irrigation on metabolic pathway during grain filling of kernel (Figure 1(b)). However, the lack of CP since 1-yr through the 3-yr wheat meadow and wheat mixture rotations under rainfed and irrigated condition was related to the content of $\mathrm{OM}$ in topsoil (Figure 1(b)) $[5,7,21,22]$.

The effect of irrigation interferes with physiological process of crops during plant development and growing. The higher values of WUE in continuous wheat for whole stem and seed production in wheat meadow and wheat mixture rotations under rainfed and irrigation treatment $(9.4 \%$ and $25.4 \%$ in rainfed and $18.1 \%$ and $33.6 \%$ in irrigated, respectively) was a consequences of OM of forage crops rotations in topsoil (Table 3 and Figure 4(b)). The lower value of WUE of 1-yr in wheat meadow and wheat mixture SY than 2-yr and 3-yr rotations in wheat meadow under both irrigated treatment evidenced that the benefit of forage crop rotations expire its effect since the 2-yr wheat rotation (Figures 1(a), 4(b) and Table 3) [7, 21]. According to Rinaldi and Ubaldo [12] and Cui et al. [1], the higher values of WUE of the wheat meadow and wheat mixture rotations under irrigated than rainfed treatment, was a consequence of the delay of vegetative cycle (on average 12 days, data not 
shown) of wheat favoured by water supply which exposed the organs of plant to a longer period of transpiration with a consequent use of water for respiration rather than WUE of physiological process $[5,19,20]$.

\subsection{Forage Crop Rotations}

The contrasting mean square values of irrigation treatment observed in DM trait between mixture and meadow was ascribed to the different fitness of the crops to Mediterranean weather condition [23,24]. The higher values of mean squares irrigation and harvest than rotation evidenced a reduction of agronomic effect of rotations on DM trait. Furthermore, the lack of statistical significant in DM among the two-way $(\mathrm{I} \times \mathrm{Y}$ and $\mathrm{I} \times \mathrm{R})$ and three-way $(\mathrm{I} \times \mathrm{R} \times \mathrm{Y})$ interaction factors in mixture rather than meadow was due to spring vegetative stasis which reduced the effect of irrigation on crop development of regrowth during the period of evaluation (Table 3) $[23,24]$.

The relationship between grass over legume in mixture rotations was influenced by irrigation treatment $(6.1 \%$ higher than rainfed) and harvest which reduced the effect of grass plant development over legume in the II harvest (15.5\% higher than those of rainfed) (data not shown) whose decrease, in both rainfed and irrigated treatment (55.9\% and $44.5 \%$ lower than I harvest under rainfed and irrigation, respectively), was due to reduction of sensitiveness of vegetative stasis which interferes with physiological process of plant development. Therefore, according to Martiniello and Teixeira da Silva [25], the autumn winter vegetative habitus of mixture advantages the crops to grow in months with meteorological event more favourable to plant development than meadow (Table 1(a)). Thus, the reduced number of harvests of mixture in comparison to meadow and the reduced DM in the III harvest of mixture under irrigated treatment, was due to the effect of weather condition on vegetative stasis which reduced the WUE $\left(91.3\right.$ and $73 \mathrm{~L}\left[(\mathrm{~kg} \cdot \mathrm{DM})^{-1}\right]$ in rainfed and irrigated condition, respectively) of plant development (Figure 2(b), Table 3).

According to Martiniello [24] and Martiniello and Teixeira da Silva [25], the decline of DM across the I to VI harvest of meadow (2.03 $\left.\mathrm{t} \cdot \mathrm{ha}^{-1}\right)$ under irrigation was a consequence of senescence of organs (root, stem and leaf) which reduced physiological process of plant develop- ment during summer vegetative growth (Figure 3(b)).

The impact of weather condition on forage crops was influenced by irrigation which interfered with physiological mechanisms increasing the period of crop utilization, number of harvests and WUE (Figures 2(b), 3(b), Table 3). The WUE of irrigation treatment (difference mean of rotations between WUE under irrigated and rainfed) was $15.4\left[\mathrm{~L}(\mathrm{~kg} \cdot \mathrm{DM})^{-1}\right]$ in meadow and $17.3[\mathrm{~L}$ $\left.(\mathrm{kg} \cdot \mathrm{DM})^{-1}\right]$ in mixture favouring longer period of physio- logical process of plant development (Table 3). The variation of WUE values of mixture and meadow rotation under rainfed and irrigation treatments $(91.3 \mathrm{vs}$ $73.0\left[\mathrm{~L}(\mathrm{~kg} \cdot \mathrm{DM})^{-1}\right]$ in mixture and 81.0 vs $67.8[\mathrm{~L}$ $(\mathrm{kg} \cdot \mathrm{DM})^{-1}$ ] in meadow) was due to different edaphic adaptability of the crops to weather conditions of the environment which favoured physiological characteristics able to conferred longer period of agronomic exploitation of meadow than mixture (3 harvests in mixture and 6 in meadow) which determine higher gap between rainfed and irrigated DM production (5.03 vs. $8.91 \mathrm{t} \cdot \mathrm{ha}^{-1}$ in mixture and 5.53 vs. $13.13 \mathrm{t} \cdot \mathrm{ha}^{-1}$ in meadow) (Figures 2(b) and 3(b)).

\subsection{Effect of Wheat Forage Crop Rotations on OM of Topsoil}

The agronomic effect of forage crop rotations influenced the turnover of OM and the chemical characteristics of topsoil [2,6,27,28]. As postulated by Hudson [29], Reeves [22] and Martiniello [4], the higher OM content in topsoil of wheat meadow and wheat mixture rotations than continuous wheat favour the mineralization of residues for producing nutrients cycling for SY, CP of kernel and microbial biomass in the rhizosphere $[1,2,4]$.

The advantages derived from meadow and mixture on wheat forage crops rotations was due to the amount of the biochemical compounds left in the soil which increased, by microbial mineralization process, the amount of nutrients required for support the higher seed production of wheat rotations under irrigated than those under rainfed (Figures 1(a) and 4(a)) [4,22,30]. Thus, the agronomic practices which alternate three years of continuous wheat rotations with as many as years of forage crops are able to restore the turnover content of OM in topsoil and increase the WUE of the crops (Figures 1(a), 4(b) and Table 3$)$.

In agreement to De Vita et al. [7], García del Moral and Rharrabti [5] and Martiniello [4], the higher SY and content of CP in the kernel under both condition of irrigation, observed in the 1-yr wheat meadow and wheat mixture than those of 2-yr and 3-yr rotations, was a consequences of meadow and mixture rotations which increased the content of OM in the topsoil (Figures 1(a), 1(b), 4(a) and 4(b)). However, the agronomic advantages achieved in topsoil by 3 -yr meadow and mixture forage crop rotations in both irrigated conditions, expired its effect after 3-yr wheat meadow and 3-yr wheat mixture rotation (Figures 1(a) and 4(a)).

The reduction of OM of wheat meadow and wheat mixture under irrigated rotations $(21.3 \%$ and $31.5 \%$ lower than rainfed, respectively) was a consequences of microbial activity for sustaining the higher SY in wheat rotations under irrigated treatment (Figures 1(a) and 
4(a)). In agreement with the results found by GarridoLestache et al. [26], Pagliai et al. [21] and De Vita et al. [7], the higher content of OM in the 1-yr wheat meadow under rainfed than others rotations, support high soil fertility for increasing the content of kernel CP (Figures 1(a) and $\mathbf{1}(\mathbf{b}))$.

According to Errebhi et al. [27], Mohammod [28] and Tilman et al. [2], the lower content in OM in 3-yr wheat meadow and wheat mixture than other rotations of rainfed and irrigated treatment was due to microbial activity which reduced the content of OM for providing nutrient cycling for plant growth (Figure 1(a)). The higher reduction of $\mathrm{OM}$ in the meadow and mixture under irrigated than rainfed evidenced un higher microbial activity for sustaining the nutrient demand for the aerial plant development [27,28] (Figures 1(a) and 4(b)).

The forage crops included in the rotation system allow the agronomic opportunity to guarantee the turnover and the restore of $\mathrm{OM}$ in the soil and as consequences increased WUE and microbial activity for sustain crop development. However the agronomic benefit achieved by forage crops on wheat meadow and wheat mixture expired its effect after 3-yr of continuous wheat rotations. Thus, the wheat forage crops rotations adopted in the experiments may represent the farming agronomic approaches able to recover the turnover content of $\mathrm{OM}$ in topsoil and sustain the performance of SY and CP of kernel in Mediterranean-type of environment.

\section{CONCLUSIONS}

The crop system used in the study represents an agronomic approach for developing sustainable agriculture in environment with Mediterranean-type climate. The three year continuous meadow and mixture forage crops rotations guaranty the turnover of OM content of the beginning experiment in topsoil and increase production and stability of SY and CP of kernel. The advantages of forage crops on OM of topsoil, expires their effect after 3 years of continuous wheat which, particularly under irrigated condition, reduced the content of OM, SY and stability of yield and qualitative characteristics of kernel.

\section{ACKNOWLEDGEMENTS}

The author is grateful to the Italian Ministry of Agricultural, Food and Forest Politicises for providing fund for supporting long term experiments. Furthermore, the author like to thanks the colleagues, technicians, scholarships, labours and soil chemistry laboratory of Bonassisa for the assistance given during the years of the evaluation of experiments.

\section{REFERENCES}

[1] Cui, H., Wang, B., Ma, B., Wang, Y., Jing, H. and Lu, L.
(2009) Effect of crop rotation and irrigation on wheat and water use efficiency. Chinese Journal of Eco-Agriculture, 17, 479-483. doi:10.3724/SP.J.1011.2009.00479

[2] Tilman, D., Cassman, K.C., Matson, P.A., Naylor, R. and Polasky, S. (2009) Agricultural sustainability and intensive production practices. Nature, 418, 671-677. doi:10.1038/nature 01014

[3] Katupitiya, A., D.E., Eisenhauer, R.B., Ferguson, R.F. Splanding, Roeth, F.W. and Bobier, M.V. (1997) Longterm tillage and crop rotation effects on residual nitrate in the crop rotation zone and nitrate accumulation in the intermediate vadose zone. Transaction of the ASABE, 40, 1321-1327.

[4] Martiniello, P. (2007) Biochemical parameters in a Mediterranean soil as affected by wheat-forage rotation and irrigation. European Journal of Agronomy, 26, 198-208. doi:10.1016/j.eja.2006.09.009

[5] García del Moral, L.F. and Rharrabti, Y. (2007) Environmentally induced changes in amino acidic composition in the grain of durum wheat grown under different water and temperature regimes in a Mediterranean environment. Journal of Agronomy and Food Chemistry, 55, 81448151. doi:10.1021/jf063094q

[6] Martiniello, P. (2011) Cereal-forage rotations effect on biochemical characteristics of topsoil and productivity of the crops in Mediterranean environment. European Journal of Agronomy, 35, 193-204. doi:10.1016/j.eja.2011.06.002

[7] De Vita, P., Di Paolo, E., Fecondo, G., Di Fonzo, N. and Pisante, M. (2007) No-tillage and conventional tillage affects on durum wheat yield, grain quality and soil mixture content in southern Italy. Soil and Tillage Research, 92, 69-78. doi:10.1016/j.still.2006.01.012

[8] FAO-ISRIC-ISSS (1998) World reference base for soil resources. World Soil Resources Report Nr. 84, FAO, Rome.

[9] Ministero delle Politiche Agricole (1999) Metodi ufficiali di analisi chimiche del suolo. Gazzetta Ufficiale Italiana Nr. 248, Rome.

[10] Doorenbos, J. and Kassam, A.H. (1980) Réponse des Rendement à l'eau. Irrigation et de Drainage. Bulletin FONI Nr. 33, FAO, Rome, Italy.

[11] Acutis, M., Perego, A., Bernardoni, E. and Rinaldi, M. (2010) AQUATER software as a DSS for irrigation management in semi-arid Mediterranean areas. Italian Journal of Agronomy, 5, 205-215. doi:10.4081/ija.2010.205

[12] Rinaldi, M., Ubaldo, R. (2007) Spatial simulation of water use efficiency in a Mediterranean environment. Water Resources Management, 4, 569-581.

[13] Steel, R.G.D. and Torrie, J.H. (1980) Principles and procedures of statistics. A biometrical approach, 2nd Edition, McGraw-Hill Book Company, New York.

[14] SAS (1997) Institute SAS/STAT software: Changes and enhancements through release 6.1. SAS Institute Inc., Cary.

[15] Eberhart, S.A. and Russell, W.A. (1966) Stability pa- 
rameters for comparing variety. Crop Science, 6, 36-40. doi:10.2135/cropsci1966.0011183X000600010011x

[16] Pagliai, M., Raglione, M., Panini, T., Maletta, M. and La Marca, M. (1995) The structure of two alluvial soils in Italy after 10 years of conventional and minimum tillage. Soil and Tillage Research, 34, 209-223. doi:10.1016/0167-1987(95)00471-4

[17] Dobermann, A. (2007) Nutrient use efficiency. Measurement and management. In: Kraus, A., Isherwood, K. and Heffer, P., Eds., Fertilizers Best Management Practices. Proceeding of International fertilizer Industry Association, Brussels, Belgium, 7-9 March 2007, 1-22.

[18] Fares, C., Dattoli, M.A., Schiavone, M.G., Menga, V. and Martiniello, P. (2009) Agricoltura sostenibile. Influenza delle rotazioni cerealicole-foraggere sulle caratteristiche di Triticum durum Desf. in ambiente meridionale. In: Bindi, M., Ed., Proceeding of 38th Meeting of Italian Society of Agronomy, 21-23 September, Florence, Italy, 433435.

[19] Tedeschi, P. and Zerbi, G. (1987) Influenza dello stress idrico su aspetti fisiologici e su alcuni parametri quantitativi delle rese di grano duro. Rivista di Agronomia, 21, 216-222.

[20] Simane, B., Struik, P.C., Nachit, M.M. and Peacock, J.M. (1993) Ontogenic analysis of yield components and yield stability of durum wheat in winter-limited environments. Euphytica, 71, 211-219. doi:10.1007/BF00040410

[21] Pagliai, M., Vignozzi, N. and Pellegrini, S. (2004) Soil structure and the effect of management practices. Soil and Tillage Research, 79, 131-143. doi:10.1016/j.still.2004.07.002

[22] Reeves, D.W. (1997) The role of soil organic matter maintaining soil quality in continuous cropping system. Soil and Tillage Research, 43, 131-167. doi:10.1016/S0167-1987(97)00038-X

[23] Martiniello, P. (1999) Effects of irrigation and harvest management on dry matter yield and seed yield of annual clovers grown in pure stand and in mixtures with graminaceous species in a Mediterranean environment. Grass and Forage Science, 54, 52-61. doi:10.1046/j.1365-2494.1999.00153.x

[24] Martiniello, P. (2009) Adaptability of lucerne, cocksfoot and tall fescue genotypes in Mediterranean environment under different application of water. European Journal of Plant Science and Biotechnology, 3, 86-96.

[25] Martiniello, P. and Teixeira da Silva, J. (2011) Physiological and bioagronomical aspect involved in growth and yield components of cultivated forage species in Mediterranean environments. European Journal of Plant Science and Biotechnology, 5, 64-98.

[26] Garrido-Lestache, E., López-Bellido, R.J. and LópezBellido, L. (2004) Durum wheat quality under Mediterranean conditions as affect by $\mathrm{N}$ rate, timing and splitting, $\mathrm{N}$ form and S fertilization. European Journal of Agronomy, 23, 265-278. doi:10.1016/j.eja.2004.12.001

[27] Errebhi, M.A., AbdelGadir, A.H. and Ben Sarhan, H. (2004) Potassium rate effect on plant uptake and forage yield of barley (Hordeum vulgare L.) grown in an arid environment. Plant Management, Network. doi:10.1094/CM-2004-0609-01-RS

[28] Mohammod, I. (2009) Effect of residue qualities on decomposition rates, soil phosphorous dynamics and plant phosphorous uptake. Adelaide Research and Scholarship Thesis. http://hdl.handle.net./20440/49812

[29] Hudson, B.D. (1994) Soil organic matter and available water capacity. Journal of Soil and Water Conservation, 49, 189-194.

[30] Kumar, K.M. and Goh, K. (2000) Crop residues and management practices: Effects on soil quality, soil nitrogen dynamics, crop yield and nitrogen recovery. Advances in Agronomy, 68, 197-319. doi:10.1016/S0065-2113(08)60846-9 